\title{
MICRO ENTERPRISES CREDITING. PRACTICAL ASPECTS
}

\author{
Mariana Rodica ṬÍRLEA \\ "Dimitrie Cantemir" Christian University, Bucharest \\ rodica.tirlea@cantemircluj.ro
}

\begin{abstract}
In a market economy, the credit assures a transfer of repayable value for a limited period of time in exchange for a price that is referred to as interest on credit. The role of the credit is to generate liquidity flows for its beneficiary in such a way as to enable him, on the one hand, to honour his obligations to the bank, namely the payment of the monthly rate of credit, interest, bank commissions as well as the insurance of the contracted loan and on the other hand to obtain a profit. In order to benefit from loans, micro-enterprises are analyzed by banks through methods, policies, tools and techniques of each bank. The credit decision will be taken by the bank only after it has ensured that potential borrowers are in line with the rules and lending regulations of the lending bank.
\end{abstract}

Keywords: credit, interest, bank fees, micro-enterprise, repayment schedule, refinancing, rescheduling

\section{JEL CODE: E 40, E 51, E 59, D 59.}

\section{Introduction}

Financial capital is a limited source. There are sometimes situations in the micro-enterprises in which, in order to ensure the functioning of their normal activity and for their economic development and growth, micro-enterprises resort to external financial sources of bank loans. It is the moment when microenterprises cannot satisfy one need or another by their own forces.

The external lending financing solution is a solution that involves additional costs and involves the management to an efficient governance of the contracted credit in such a way that the use of committed credit generates added value that ensures maximum efficiency of its use at microenterprise level. In order to ensure at one time the "best correlation and at the same time the compatibility between the economic optimum and the financial optimum, which in the market economy holds the primacy, there can be found in the" identification "of the financial phenomena in principle with the economic ones, in the real, quantitative and especially qualitative interdependencies that are established between these two sides of the economic process, because they have permanent contact points" [3].

Dictionary of Banking Terms, defines credit as: "an agreement whereby certain goods, services, or a quantity of currency are ceded in exchange for a future payment promise" [2]. In order to lend credits to micro-enterprises, banks are considering:

- banking caution;

- limitation of risks;

- involving as few risks as possible;

- compliance with credit principles.

The principles governing bank lending can be presented as such: 
Table 1.Credit Principles

\begin{tabular}{|c|c|c|}
\hline $\begin{array}{l}\text { No. } \\
\text { Crt. }\end{array}$ & Principle name & Significance of the principle \\
\hline 1. & $\begin{array}{l}\text { The contractual form } \\
\text { of loan contracted by } \\
\text { the microenterprise }\end{array}$ & $\begin{array}{l}\text { The credit agreement takes the written form. It is an adhesion contract } \\
\text { that contains "all credit operations and guarantees of the banking } \\
\text { companies will have to be recorded in contract documents clearly } \\
\text { showing all the terms and conditions of the respective transactions" [1]. }\end{array}$ \\
\hline 2. & $\begin{array}{l}\text { Credibility of the } \\
\text { bank client - micro } \\
\text { enterprise }\end{array}$ & $\begin{array}{l}\text { Knowledge of the client in the following aspects: the moral, professional } \\
\text { qualities of the associates and the managers of the society, the relations } \\
\text { with the clients, the suppliers, the collaborators; reputation, quality of } \\
\text { products and services offered on the market; the patrimonial and } \\
\text { financial situation etc. }\end{array}$ \\
\hline 3. & $\begin{array}{l}\text { The destination of the } \\
\text { loan contracted by the } \\
\text { micro-enterprise }\end{array}$ & $\begin{array}{l}\text { Granting and using credit is only for legal activities. The client of the } \\
\text { bank has the obligation to use the credit only for the purpose for which it } \\
\text { was granted. According to this principle, the bank is entitled throughout } \\
\text { the entire period of the credit to follow the way it is used. }\end{array}$ \\
\hline 4. & $\begin{array}{l}\text { Profitability of the } \\
\text { client-micro } \\
\text { enterprise }\end{array}$ & $\begin{array}{l}\text { The bank grants the credit and takes the credit decision only after the } \\
\text { client's creditworthiness analysis has been performed. }\end{array}$ \\
\hline 5. & $\begin{array}{l}\text { Responsibility of the } \\
\text { analysis regarding } \\
\text { client-micro- } \\
\text { enterprise }\end{array}$ & $\begin{array}{l}\text { Responsibility implies analysing with maximum accountability the } \\
\text { client's need for credit and the risk incurred by it. }\end{array}$ \\
\hline 6. & Common sense & $\begin{array}{l}\text { The client will be studied enough, so that the bank's good reputation } \\
\text { will not be affected. }\end{array}$ \\
\hline 7. & $\begin{array}{l}\text { Credit repayment by } \\
\text { the client-micro } \\
\text { enterprise according } \\
\text { to the deadlines } \\
\text { stipulated in the credit } \\
\text { agreement }\end{array}$ & $\begin{array}{l}\text { This principle balances the credit process and ensures the continuity of } \\
\text { the process. The main measures that ensure the implementation of this } \\
\text { principle are the real determination of the applicant's ability to earn } \\
\text { income, the permanent supervision of the way the credit is used and the } \\
\text { arrangement of the insuring guarantees. The non-repayment of the credit } \\
\text { at the date stipulated in the contract entails penalties as well as the } \\
\text { commencement of the forced execution procedure. }\end{array}$ \\
\hline 8. & Credit Guarantee & $\begin{array}{l}\text { Credit guarantee is provided with: } \\
\text { - movable property; } \\
\text { - immobile goods; } \\
\text { - } \text { bank bonds; } \\
\text { - securities. } \\
\text { Bank guarantees are means of diminishing the risk of insolvency and } \\
\text { represent another source of credit repayment. The bank guarantees } \\
\text { provided by the client which are at the disposal of the bank are to cover } \\
\text { the amount borrowed and the interests related thereto. The goods with } \\
\text { which the credit has been guaranteed remain in the client's use but the } \\
\text { bank becomes the owner until full payment of the credit, for which } \\
\text { reason the bank institution has the right and the obligation to verify the } \\
\text { permanent existence of the assets offered to the guarantors. }\end{array}$ \\
\hline
\end{tabular}

Source: Author

Banking activity is an important segment of the economy. Banks are intended for their activities under the law to attract resources and savings on the one hand and to grant credits on the other hand to meet the needs of society, namely individuals and legal persons.
Banking prudence is the corollary that governs lending activity in full consonance with the following general principles: the contractual form of the credit, the credibility of the client of the bank, the destination of the credit, the repayment of 
the credit, the profitability, the common sense and the responsibility.

Banks should be mindful regarding the compliance with these principles in order for the crediting activity to take place normally and involve as few risks as possible.

\section{The Importance of Micro-Enterprise} Liquidity Rates in the Lending Process

Historical liquidity information mirrors the ability of the micro-enterprise to obtain a surplus of liquidity. In practice, the chainbased indicator method is used because it highlights and redefines the crests or misinterpretations of all components of the cash flow of the period of management reported in the previous year.
Cash flows confirm or invalidate for a given period if:

- an additional cach-flow has been generated for:

$\checkmark$ Financing of investments;

$\checkmark$ Financing the current micro-enterprise activity.

- the decisions of the previous years were rational;

- the decisions of the previous years have contributed to the economic equilibrium of the micro-enterprise;

- decisions of previous years have been effective,

- the decisions of the previous years were real;

- have contributed to the balance of economic optimum of the micro-enterprise.

Table 2. The liquidity situation of the micro enterprise SC Q S.R.L. for the years, Lei

\begin{tabular}{|c|l|r|r|r|}
\hline $\begin{array}{c}\text { No. } \\
\text { crt. }\end{array}$ & \multicolumn{1}{|c|}{ Economic and financial indicators } & $\begin{array}{c}\text { Year } \\
\mathbf{2 0 1 6}\end{array}$ & $\begin{array}{c}\text { Year } \\
\mathbf{2 0 1 7}\end{array}$ & \multicolumn{1}{c|}{$\begin{array}{c}\text { Year } \\
\mathbf{2 0 1 8}\end{array}$} \\
\hline 1 & Current assets & 920.771 & 949.469 & 1.148 .951 \\
\hline 2 & from which: - stocks & 882.912 & 911.215 & 1.106 .380 \\
\cline { 2 - 5 } & \multicolumn{1}{|c}{ - clients } & 18.210 & 14.231 & 12.333 \\
\cline { 2 - 5 } & \multicolumn{1}{|c}{ - bank accounts } & 1.045 & 2.500 & 2.640 \\
\cline { 2 - 5 } & - house & 5.354 & 6.111 & 11.236 \\
\cline { 2 - 5 } & \multicolumn{1}{|c}{ other values } & 13.250 & 15.412 & 16.362 \\
\cline { 2 - 5 } & Short term debts & 60.225 & 51.310 & 35.441 \\
\hline 3 & Liquidity & 860.546 & 898.159 & 1.113 .510 \\
\hline 4 & Fiscal value & 1.208 .963 & 1.311 .222 & 1.425 .327 \\
\hline 5 & The cost of sales & 1.112 .233 & 1.255 .346 & 1.257 .888 \\
\hline
\end{tabular}

Source: Author

Figure 1: The liquidity situation of the micro enterprise SC Q S.R.L. for the years

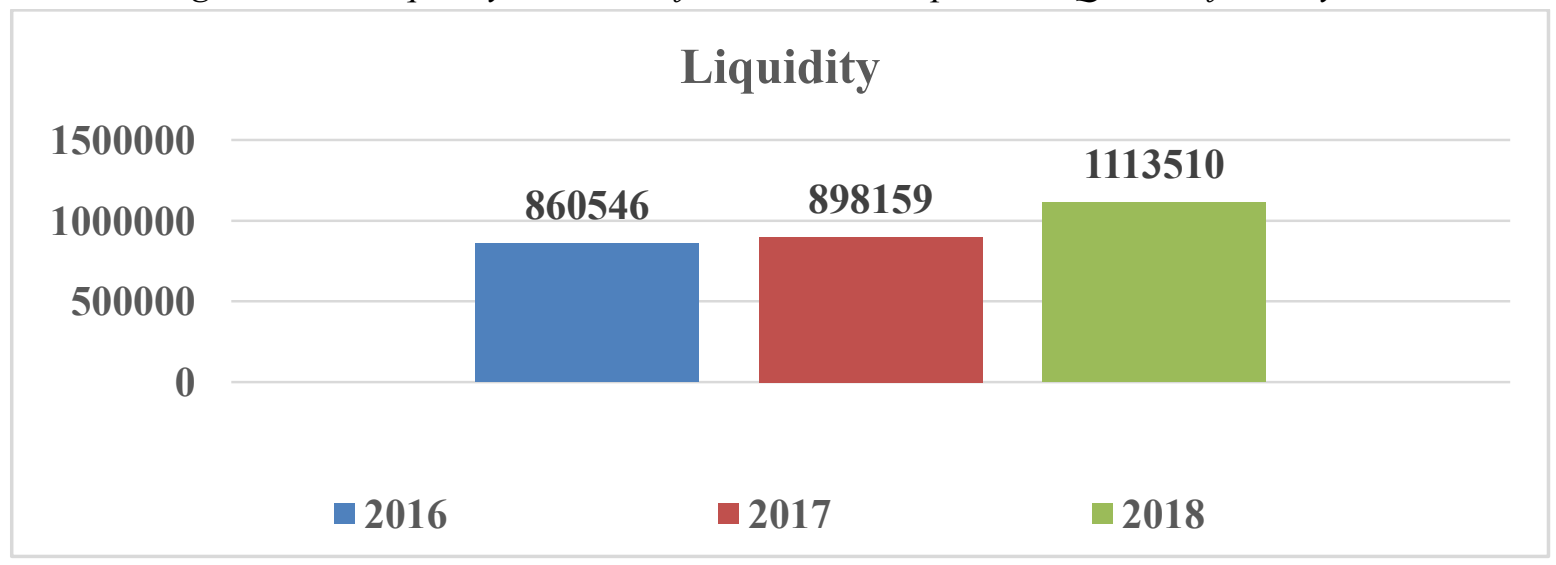

Source: Author

It follows that, from one year to another, we have a liquidity increase of +50.863 lei in year 2 and +784649 . in year 3, which confirms good management performance in 
this area.

Practically, this has been achieved through a faster growth of placements in more liquid assets - cashand cash customers atthe expense of the slow-liquid stocks of raw materials and manufactured products.

The calculation of liquidity rates is determined according to the calculation formulas:

Liquidity rates:

1. Current liquidity $=$ Current assets/ short term debts

2. Immediate liquidity $=$ current assets stocks/ short term debts

3 . The average duration of debt payments $=$ debts to creditors/ the cost of sales /360

The purpose of microfinance liquidity rates is as follows:

1. liquidity ratios are designed to measure the ability of a micro-enterprise to honor its short-term monetary obligations on its creditors;

2. leverage ratios measure the proportion that the enterprise is able to finance through its own resources and debt.

\section{Measuring the Economic and Financial Indicators and the Results of Micro-Enterprises}

The Coefficients Method is a specific method for financial analyzes, which provides the financial managers of microenterprises with management control. The coefficient method is expressed in percentage mathematical ratios of two selected magnitudes of significant importance which result in a coefficient. This coefficient represents for the manager a new information that is interpreted, compared to other information of the same genre and underlies future forecasts and projections. Specialist literature denotes this coefficient as a rate, and the method also appears under the name of the rate method.

The comparison of the sizes is not done by chance, the comparison of the sizes is in the form of a report of two significant quantities, among which there is an indissoluble link. These sizes, respectively amounts, are taken from the micro-enterprise accounts, respectively from check balances, annual financial statements, patrimonial situation, profit and loss account, operative records, statistical statements.

These financial accounting documents are the information base for data mining, the construction of indicators, the analysis of the results obtained, the comparison of the results obtained with the financial projections made before the results are obtained, the information for future microfinance forecasts and financial projections.

Financial accounting documents present the informational basis in a historical and conventional manner on the basis of which calculations are made, the application of methods, the obtaining of results, the comparison of the results, the interpretation of the results as a result of carrying out financial analyzes.

The historical generic data obtained from the historical data extracted from the microenterprise accounting ensures the observation of the economic and financial activity trend of the micro-enterprise.

The results obtained by grouping, computing, selecting, organizing, analyzing and interpreting are another informational source for the micro-enterprise's decision-maker, the financial manager of the micro-enterprise.

The credit decision is based on the rational model of the managerial financial decision, which in a schematic form is thus presented:

The rational model for substantiating the lending decision at micro-enterprise level:

1. Rationality of the micro-enterprise lending decision based on real, accurate, valuable, timely information that would enable the user to achieve the desired efficiency for future actions.

2. Rationality of the credit decision adopted.

The proposed objectives for sustaining lending will be based on economic and financial fundamentals to achieve maximum results and maximum efficiency.

3. The rationality of the process of adopting the credit decision at the microenterprise level, based on the realities of the 
micro-enterprise obtained through a sequence of logical, clear, concise and achievable steps by the micro-enterprise following:

- profitability;

- the management of assets,

- the financing of assets.

\section{Conclusions}

The materialization of the lending decision must contribute to the achievement of the financial optimum, the optimal economic and lead to the development and growth of the micro-enterprise.

The growth and economic development of the micro-enterprise is represented by a complex process marked by new quantitative dimensions reflected as a result of the mentioned process and determined by a set of indicators by means of which the microeconomic growth is measured and expressed. Referred to the managerial decision to lend, reaching the levels predicted by the microenterprise implies:

a) identification of external lending financial resources;

b) analysis and selection of financial resources at the most advantageous costs for micro-enterprises;

c) obtaining funding sources at the right time;

d) obtaining the financing sources at the level of the financing needs of the microenterprise;

e) maximizing the efficiency of the funding;

f) the loan commitment taken by the microenterprise will consider:

- the efficiency of the use of contracted credit;achieving the proposed objectives;

- achieving the fundamental goal of small business, that of maximizing profit;

- achieving planned parameters;
- coverage of bank interest charges;

- covering bank charges;

- coverage of insurance costs;

- obtaining additional income;

- making a profit;

g) rationalizing the use of contracted credit strictly to destinations that allow the microenterprise to obtain the parameters that are required of it;

h) he efficiency of use

i) increasing the level of economic efficiency at micro-enterprise level;

j) ensuring the economic optimum of the micro-enterprise;

k) ensuring the connections between the financial optimum and the economic optimum of the micro-enterprise;

1) harmonizing the financial optimal with the economic optimum of the micro-enterprise.

The indicators used in the economic and financial analysis and the management of the micro-enterprise are reflected in:

1) indicators of resource management;

2) indicators of financial return and profitability;

3) indicators of the enterprise's financial position;

4) indicators of the market value of the enterprise.

In practice, the purpose of calculating rates is reflected in the fact that:

1) liquidity ratios measure the firm's ability to honor its short-term monetary obligations on its creditors;

2) leverage ratios, measure the proportion of the enterprise's financing on its own resources and contracted liabilities;

The ultimate goal is to achieve good correlations and compatibility between the economic optimum and financial optimum.

[1] Law 33/91 on banking activity in Romania.

[2] Fitch, T., Dictionary of Banking Terms, New York, 1993.

[3] Trenca, I., Considerations regarding the financial optimum - component of the economic optimum, Studia Económica Magazine, No. 2/1988, Babeş-Bolyai University.

[4] Tîirlea, M.R., Financial Banking Management - Lithogarified course support, 2016, UCDC Cluj. 